\title{
Flavobacterium indicum sp. nov., isolated from warm spring water in Assam, India
}

\author{
P. Saha and T. Chakrabarti \\ Microbial Type Culture Collection and Gene Bank (MTCC), Institute of Microbial Technology \\ (IMTECH), Sector 39A, Chandigarh 160 036, India
}

Correspondence

T. Chakrabarti

tapan@imtech.res.in
The description of the genus Flavobacterium, created by Frankland in 1889 (Bergey et al., 1923), has been emended twice during the last 10 years (Bernardet et al., 1996, 2002). Members of the family Flavobacteriaceae have been reported from diverse aquatic habitats (Bernardet et al., 1996), where they may be significantly involved in the uptake and degradation of the high-molecular-mass fraction of dissolved organic matter (Kirchman, 2002), in the degradation of several biopolymers (Glöckner et al., 1999; Bernardet et al., 2002) and in the bacterioplankton biomass (Brettar et al., 2004). Here we report the taxonomic characterization of strain GPTSA100-9 $9^{\mathrm{T}}$, isolated from warm spring water in Assam, India. The spring was located in a forest reserve not disturbed by human activities but frequented by wild animals, especially elephants, which was evident from the surrounding dung. The spring water was clear and its temperature was $37-38^{\circ} \mathrm{C}$.

Strain GPTSA100-9 $9^{\mathrm{T}}$ was isolated by plating serial dilutions on a nutritionally poor medium, TSBA100 [tryptic soy broth (Difco), $100 \times$ diluted with distilled water and solidified with $1.5 \%$ agarose (SRL)]. Various phenotypic tests were performed according to standard methods (Cowan \& Steel, 1965; Murray et al., 1994; Smibert \& Krieg, 1994; Powers, 1995). Growth at different temperatures $(10,15,20,25,30$, 37,42 and $\left.55^{\circ} \mathrm{C}\right), \mathrm{pH}$ values $(5,6,7,8,9,10,11$ and 12$)$ and

The GenBank/EMBL/DDBJ accession number for the $16 \mathrm{~S}$ rRNA gene sequence of strain GPTSA $100-9^{\top}$ is AY904351.
$\mathrm{NaCl}$ concentrations $(1,2,5,7$ and $10 \%, \mathrm{w} / \mathrm{v})$ was determined using TSBA100 as a basal medium. Temperature and $\mathrm{pH}$ tolerances were also assessed in liquid MR2A medium. Since the strain had been isolated on a nutritionally poor medium, we also assessed its ability to grow on the following media: MR2A agar (Saha \& Chakrabarti, 2006), R3A agar [essentially according to Reasoner \& Geldreich (1985) except that proteose peptone no. 2 and $0.0048 \% \mathrm{MgSO}_{4} .7 \mathrm{H}_{2} \mathrm{O}(\mathrm{w} / \mathrm{v})$ were used instead of proteose peptone no. 3 and $0.01 \% \mathrm{MgSO}_{4} \cdot 7 \mathrm{H}_{2} \mathrm{O}$, respectively], nutrient agar (Hi-Media), MacConkey agar (HiMedia), LY agar (Reichenbach, 1989), cytophaga agar (Anacker \& Ordal, 1959, as mentioned in Reichenbach, 1989), undiluted tryptic soy broth agar (TBSA), LuriaBertani agar (Difco) and ZoBell marine agar (Hi-Media). The presence of gliding motility was assessed on MR2A agar as described by Bowman (2000) and in liquid MR2A and TSB100 media. For the detection of flexirubin-type pigments, bacterial cell mass was exposed to a $20 \%$ (w/v) $\mathrm{KOH}$ solution, as described by Reichenbach (1989); this was then examined for an eventual colour shift.

The hydrolysis of aesculin, cellulose (filter paper), chitin, tyrosine, hypoxanthine, starch, casein $(2 \cdot 8 \%, \mathrm{w} / \mathrm{v})$, DNA and gelatin was assessed according to standard protocols (Cowan \& Steel, 1965; Smibert \& Krieg, 1994), except that MMR2A agar (MR2A medium without glucose, starch and sodium pyruvate) was used as the basal medium. The hydrolysis of carboxymethylcellulose (Sigma) was assessed as reported previously (Saha \& Chakrabarti, 2006). The 
hydrolysis of alginate and pectin was investigated according to the methods described by Nakamura (1987) and Stanley et al. (1989), respectively. Acid production from various carbohydrates $(0.5 \%, \mathrm{w} / \mathrm{v})$ and the hydrolysis of urea $(2 \%$, $\mathrm{w} / \mathrm{v}$ ) were tested in basal MMR2A broth, using phenol red as an indicator. The hydrolysis of ONPG was assessed using an ONPG disc (Hi-Media). To determine the utilization of sole carbon sources, basal medium [containing (w/v) $0.2 \%$ $\left(\mathrm{NH}_{4}\right)_{2} \mathrm{SO}_{4} ; 0.024 \% \quad \mathrm{~K}_{2} \mathrm{HPO}_{4} ; \quad 0.024 \% \quad \mathrm{MgSO}_{4} .7 \mathrm{H}_{2} \mathrm{O}$; $0.01 \% \mathrm{KCl} ; 0.01 \%$ yeast extract and $1.5 \%$ agarose] was supplemented with the respective carbon sources $(1 \%)$. The production of $\mathrm{H}_{2} \mathrm{~S}$ from cysteine was assessed by placing a lead acetate paper strip above a culture in MMR2A broth supplemented with $0.05 \%$ cysteine. The reaction with egg yolk was investigated using MMR2A agar supplemented with $1 \%$ egg yolk. All biochemical tests were incubated at $37^{\circ} \mathrm{C}$.

Antibiotic susceptibility was investigated on MR2A agar, using discs (Hi-Media) containing antibiotics at the following concentrations: $10 \mu \mathrm{g}$ ampicillin; $8 \mathrm{U}$ bacitracin; $30 \mu \mathrm{g}$ chloramphenicol; $15 \mu \mathrm{g}$ erythromycin; $10 \mu \mathrm{g}$ gentamicin; $30 \mu \mathrm{g}$ kanamycin; $2 \mu \mathrm{g}$ lincomycin; $30 \mu \mathrm{g}$ neomycin; $30 \mu \mathrm{g}$ novobiocin; $10 \mu \mathrm{g}$ norfloxacin; $10 \mathrm{U}$ penicillin G; $300 \mathrm{U}$ polymyxin $\mathrm{B} ; 2 \mu \mathrm{g}$ rifampicin; $10 \mu \mathrm{g}$ streptomycin; $300 \mu \mathrm{g}$ sulfasomidine and $3 \mu \mathrm{g}$ tetracycline. On MR2A agar, 5-7-day-old colonies showed a thin film of translucent growth with finger-like projections emanating from their irregular margins, suggesting that the strain could exhibit gliding motility. However, the presence of gliding motility could not be confirmed using phase-contrast microscopy on bacterial cells grown in liquid media. The major phenotypic properties of the strain are given in the species description and in Table 1.

For cellular fatty acid analysis, the strain was grown on MR2A agar at $30^{\circ} \mathrm{C}$ for $24 \mathrm{~h}$. Extraction and analysis of cellular fatty acids were performed according to the procedures of the Sherlock Microbial Identification system (MIDI), as described previously (Pandey et al., $2002)$. The major fatty acids were iso- $\mathrm{C}_{15: 0}(18 \cdot 5 \%)$, iso$\mathrm{C}_{15: 1} \mathrm{G}\left(18 \cdot 0 \%\right.$ ), summed feature 3 (comprising iso- $\mathrm{C}_{15: 0}$ $2-\mathrm{OH}$ and/or $\left.\mathrm{C}_{16: 1} \omega 7 c, 16 \cdot 6 \%\right)$, iso- $\mathrm{C}_{17: 0} 3-\mathrm{OH}(9 \cdot 0 \%)$, iso- $\mathrm{C}_{16: 0}(5 \cdot 1 \%)$, iso- $\mathrm{C}_{15: 0} 3-\mathrm{OH}(5 \cdot 0 \%)$ and iso- $\mathrm{C}_{16: 0} 3-$ $\mathrm{OH}(4 \cdot 5 \%)$.

Isolation of genomic DNA and determination of the $\mathrm{G}+\mathrm{C}$ content $(\mathrm{mol} \%)$ were carried out according to published methods (Saha et al., 2005). Amplification of the $16 \mathrm{~S}$ rRNA gene was performed using primers $27 f\left(5^{\prime}\right.$ AGAGTTTGATCCTGGCTCAG- $\left.3^{\prime}\right)$ and $1492 \mathrm{r}$ (5'TACGGYTACCTTGTTACGACTT-3'). The amplification reaction and the purification of the amplicon were performed as described previously (Pandey et al., 2002). Sequencing reactions were performed using primers $27 \mathrm{f}$, 357f, 685r, 926f, 1100r (Johnson, 1994) and 1492r. The almost-complete (1396 nt) 16S rRNA gene sequence of the strain was used to search for homologous sequences in the GenBank database. Sequence analyses were also
Table 1. Differential characteristics of strain GPTSA $100-9^{\top}$ and related members of the genus Flavobacterium

Taxa: 1, strain GPTSA100-9 ${ }^{\mathrm{T}} ; 2$, Flavobacterium saliperosum; 3, Flavobacterium aquatile; 4, Flavobacterium columnare; 5, Flavobacterium soli. Data are from Holmes et al. (1984), Bernardet \& Grimont (1989), Bernardet et al. (1996, 2002), Wang et al. (2005) and Yoon et al. (2005). All of the strains are positive for growth without $\mathrm{NaCl}$ and for catalase, oxidase (except F. saliperosum) and gelatinase activities. All of the strains are negative for hydrolysis of agar, carboxymethylcellulose and chitin (except F. soli, for which no data are available). +, Positive; -, negative; W, weakly positive; ND, not determined; NDT, not detected; NG, no growth on medium tested.

\begin{tabular}{|c|c|c|c|c|c|}
\hline Characteristic & 1 & 2 & 3 & 4 & 5 \\
\hline Colony colour ${ }^{\star}$ & YO & $\mathrm{Y}$ & $\mathrm{CY}$ & GY & $\mathrm{CY}$ \\
\hline Flexirubin-type pigments & - & + & - & + & - \\
\hline \multicolumn{6}{|l|}{ Growth on: } \\
\hline Nutrient agar & $\mathrm{W}$ & + & - & - & ND \\
\hline Tryptic soy agar & - & + & + & - & + \\
\hline Growth at 37 and $42^{\circ} \mathrm{C}$ & + & - & - & - & - \\
\hline Tolerance of $2 \% \mathrm{NaCl}$ & + & - & - & - & + \\
\hline $\mathrm{H}_{2} \mathrm{~S}$ production & - & - & $\mathrm{W}$ & + & ND \\
\hline Nitrate reduction & - & - & + & + & + \\
\hline \multicolumn{6}{|l|}{ Hydrolysis of: } \\
\hline Aesculin & NG & - & + & - & + \\
\hline DNA & - & ND & - & + & - \\
\hline Starch & + & - & + & - & - \\
\hline Tween 20 & - & ND & + & + & + \\
\hline Tyrosine & - & + & + & - & - \\
\hline \multicolumn{6}{|l|}{ Acid production from: } \\
\hline Fructose & + & - & - & - & $\mathrm{N} / \mathrm{A} \dagger$ \\
\hline Lactose & - & - & + & - & $\mathrm{N} / \mathrm{A} \dagger$ \\
\hline Sucrose & - & - & + & - & $\mathrm{N} / \mathrm{A} \dagger$ \\
\hline \multicolumn{6}{|l|}{ Sensitivity to: } \\
\hline Gentamicin & + & + & ND & - & - \\
\hline Kanamycin & + & + & ND & - & - \\
\hline Neomycin & + & ND & ND & - & - \\
\hline DNA $G+C$ content $(\mathrm{mol} \%)$ & 31 & 41 & 33 & 32 & $36 \cdot 9$ \\
\hline $\mathrm{C}_{15: 0}$ content $(\%) \ddagger$ & NDT & $3 \cdot 9$ & $12 \cdot 7$ & $4 \cdot 4$ & $8 \cdot 2$ \\
\hline
\end{tabular}

${ }^{\star} \mathrm{CY}$, cream-yellow; Y, yellow; YO, yellowish orange; GY, greenish yellow.

$\dagger$ Not applicable (does not produce acid from carbohydrates).

$\ddagger$ The fatty acid composition was determined using bacteria grown under different conditions.

performed with various online analysis tools available in the Ribosomal Database Project II database (release 9; http://rdp.cme.msu.edu/).

The sequence analysis revealed that strain GPTSA100-9 $9^{\mathrm{T}}$ belongs to the genus Flavobacterium. Its closest relative was found to be CFB group bacterium strain A0653 (GenBank accession number AF236016; 99.8\% sequence similarity), followed by the uncultured bacterial clones HP1A39 
(AF502205; 94.4\%) from activated sludge (McMahon et al., 2002) and 169ds20 (AY212620; 94.0\%) from equine manure (Simpson et al., 2004). Among named bacteria, strain GPTSA100-9 ${ }^{\mathrm{T}}$ showed closest similarity to '[Flexibacter] aurantiacus subsp. excathedrus' IFO 16024 (93.4\%), Flavobacterium saliperosum $\mathrm{S}_{13}{ }^{\mathrm{T}}(93 \cdot 2 \%)$, Flavobacterium soli DS-6 ${ }^{\mathrm{T}}(92 \cdot 9 \%)$, Flavobacterium aquatile ATCC $11947^{\mathrm{T}}$ $(92 \cdot 1 \%)$ and Flavobacterium columnare NCIMB $2248^{\mathrm{T}}$ $(90 \cdot 0 \%)$. Sequence similarities with other members of the family Flavobacteriaceae were below 90.0 \%. Previous studies have shown that '[Flexibacter] aurantiacus subsp. excathedrus' is generically misclassified and should be considered as a species of the genus Flavobacterium pending further investigations (Bernardet et al., 1996; Nakagawa et al., 2002).

The 16S rRNA gene sequences of CFB group bacterium A0653, the uncultured bacterial clones HP1A39 and 169ds20, the type strains of 28 members of the genus Flavobacterium, '[Flexibacter] aurantiacus subsp. excathedrus' and seven closely related genera in the family Flavobacteriaceae were compared using the CLUSTAL_X program (Thompson et al., 1997) and edited manually. Aligned sequences were analysed by using the TREECON software package (Van de Peer \& De Wachter,
1997). A neighbour-joining analysis (Saitou \& Nei, 1987) was carried out using the correction of Jukes \& Cantor (1969). The stability of the tree was estimated by bootstrap analysis of 1000 replications. The resulting phylogenetic tree (Fig. 1) confirmed that strain GPTSA100-9 $9^{\mathrm{T}}$ belongs to the genus Flavobacterium. Within the monophyletic Flavobacterium lineage, strain GPTSA100-9 $9^{\mathrm{T}}$, the uncultured bacterial clone HP1A39 and CFB group bacterium A0653 together form a subcluster within the Flavobacterium aquatileFlavobacterium saliperosum cluster. Parsimony analysis (DNAPARS with 100 replicates) using PHYLIP, version 3.5c (Felsenstein, 1993), produced a tree with similar overall topology. The lack of information on CFB group strain A0653 and the low levels of sequence similarity between the novel strain and cultured relatives warrant the categorization of strain GPTSA $100-9^{\mathrm{T}}$ as a novel species in the genus Flavobacterium.

Strain GPTSA100-9 $9^{\mathrm{T}}$ could be distinguished from its close phylogenetic relatives on the basis of phenotypic characteristics, DNA G $+\mathrm{C}$ content $(\mathrm{mol} \%)$ and chemotaxonomic parameters (Table 1). Thus, on the basis of this polyphasic study, we conclude that GPTSA100- $9^{\mathrm{T}}$ represents a novel

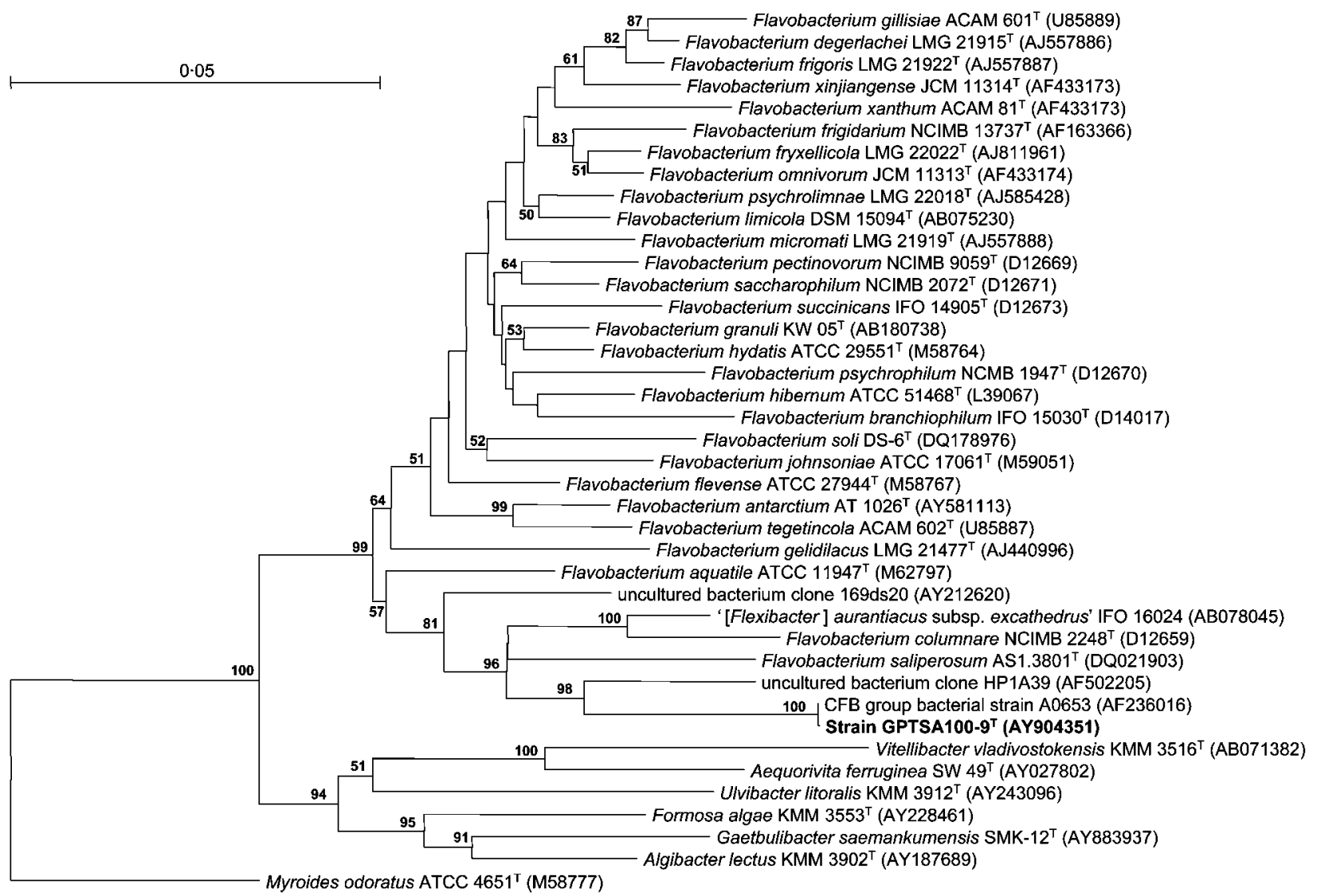

Fig. 1. Neighbour-joining phylogenetic tree, based on the comparison of $16 \mathrm{~S}$ rRNA gene sequences, showing the relationships between strain GPTSA100-9 $9^{\top}$ and the type strains of relatives within the family Flavobacteriaceae. Bootstrap values shown at the nodes are expressed as percentages of 1000 replications (if greater than $50 \%$ ). The sequence of Myroides odoratus ATCC $4651^{\top}$ was used as an outgroup. Bar, 0.05 substitutions per site. 
species of the genus Flavobacterium, for which the name Flavobacterium indicum sp. nov. is proposed.

\section{Description of Flavobacterium indicum sp. nov.}

Flavobacterium indicum (in'di.cum. L. neut. adj. indicum pertaining to India, where the bacterial strain was isolated).

Cells are Gram-negative, strictly aerobic, non-motile and occur mostly as single slender rods, but sometimes in pairs; tend to form filaments in old cultures. Cells are 1-3 $\mu \mathrm{m}$ long and $0 \cdot 1-0 \cdot 2 \mu \mathrm{m}$ wide. Colonies on MR2A agar are yellowish orange, round, convex to slightly umbonate and have irregular margins; finger-like projections appear at the margins of 5-7-day-old colonies. Colonies on TSBA100 medium are much smaller, pale yellowish in colour and more adherent to the agar than those on MR2A agar. Good growth occurs on R2A agar, R3A agar, cytophaga agar, fulland quarter-strength ZoBell marine agar, yeast extract agar and nutrient agar devoid of $\mathrm{NaCl}$. Weak growth occurs on nutrient agar, Luria-Bertani agar and LY agar. No growth occurs on tryptic soy broth, Methyl Red-Voges-Proskauer broth, Simmons' citrate agar, spirit blue agar, MacConkey agar or Kligler's iron agar. Flexirubin-type pigments are absent. Tests are positive for oxidase and very weakly positive for catalase. Grows at temperatures between 15 and $42{ }^{\circ} \mathrm{C}$ (optimum, $37^{\circ} \mathrm{C}$ ), at $\mathrm{pH} 5 \cdot 0-11 \cdot 0$ (optimum, $\mathrm{pH} 7 \cdot 4-8 \cdot 0)$ and tolerates up to $2 \% \mathrm{NaCl}$. Casein, gelatine and Tweens 40 and 60 are hydrolysed; starch is weakly hydrolysed. ONPG, tyrosine, urea, xylan, agar, aesculin, alginate, cellulose (filter paper and carboxymethylcellulose), chitin, DNA, hypoxanthine, pectin, xanthine and Tweens 20 and 80 are not hydrolysed. Negative in tests for $\mathrm{H}_{2} \mathrm{~S}$ production from cysteine. Gives a proteolytic reaction, but no precipitate, on egg-yolk agar. D-Fructose and (to a lesser extent) inulin are utilized. L-Arabinose, D-amygdalin, Dgalactose, D-glucose, glycerol, glycogen, D-mannose, Lrhamnose, D-sorbitol and L-xylose are very weakly utilized. Adonitol, D-arabinose, L-arabitol, arbutin, D-cellobiose, dulcitol, myo-inositol, D-lactose, D-mannitol, D-maltose, Dmelibiose, D-melezitose, D-raffinose, D-ribose, L-sorbose, sucrose, trehalose, xylitol and D-xylose are not utilized. Produces acid from D-fructose and (very weakly) from Dglucose, glycogen, inulin, L-xylose and D-mannose. Acid is not produced from the other carbohydrates tested. Major

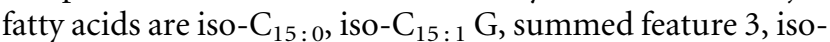
$\mathrm{C}_{17: 0} 3-\mathrm{OH}$, iso- $\mathrm{C}_{16: 0}$, iso- $\mathrm{C}_{15: 0} 3-\mathrm{OH}$ and iso- $\mathrm{C}_{16: 0} 3-\mathrm{OH}$; other fatty acids present are iso- $\mathrm{C}_{14: 0}, \mathrm{C}_{15: 1} \omega 6 c$, iso- $\mathrm{C}_{13: 0}$, $\mathrm{C}_{15: 0} 2-\mathrm{OH}$, iso- $\mathrm{C}_{17: 1} \omega 9 c, \mathrm{C}_{17: 1} \omega 6 c$, iso- $\mathrm{C}_{16: 1} \mathrm{H}$, anteiso$\mathrm{C}_{15: 0}$ and an unknown fatty acid with an equivalent chain length of $13 \cdot 565$. The DNA G $+\mathrm{C}$ content is $31 \cdot 0 \mathrm{~mol} \%$. Sensitive to ampicillin, bacitracin, chloramphenicol, erythromycin, gentamicin, kanamycin, lincomycin, neomycin, novobiocin, norfloxacin, penicillin $G$, polymyxin $B$, rifampicin, streptomycin, sulfasomidine and tetracycline.

The type strain, GPTSA100- $9^{\mathrm{T}}\left(=\right.$ MTCC $6936^{\mathrm{T}}=$ DSM $17447^{\mathrm{T}}$ ), was isolated from water sampled from a warm spring in Assam, India.

\section{Acknowledgements}

We are grateful to Dr K. Ganesan for his help with DNA sequencing. The help of Dr T. C. Bora (Biotechnology Division, Regional Research Laboratory, Jorhat, India) with sample collection is gratefully acknowledged. This work was supported by grants from DBT, Government of India and CSIR. We thank Dr A. K. Mondal, Dr G. S. Prasad and Mr S. Mayilraj for useful discussions. We also thank the Editor and the referees for making useful suggestions. P.S. is the recipient of a CSIR fellowship. This is IMTECH communication number 62/2005.

\section{References}

Bergey, D. H., Harrison, F. C., Breeds, R. S., Hammer, B. W. \& Huntoon, F. M. (1923). Genus II. Flavobacterium gen. nov. In Bergey's Manual of Determinative Bacteriology, pp. 97-117. Baltimore: Williams \& Wilkins.

Bernardet, J.-F. \& Grimont, P. A. D. (1989). Deoxyribonucleic acid relatedness and phenotypic characterization of Flexibacter columnaris sp. nov., nom. rev., Flexibacter psychrophilus sp. nov., nom. rev., and Flexibacter maritimus Wakabayashi, Hikida, and Masumura 1986. Int J Syst Bacteriol 39, 346-354.

Bernardet, J.-F., Seger, P., Vancanneyt, M., Berthe, F., Kersters, K. \& Vandamme, P. (1996). Cutting a Gordian knot: emended classification and description of the genus Flavobacterium, emended description of the family Flavobacteriaceae, and proposal of Flavobacterium hydatis nom. nov. (Basonym, Cytophaga aquatilis Strohl and Tait 1778). Int J Syst Bacteriol 46, 128-148.

Bernardet, J.-F., Nakagawa, Y. \& Holmes, B. (2002). Proposed minimal standards for describing new taxa of the family Flavobacteriaceae and emended description of the family. Int J Syst Evol Microbiol 52, 1049-1070.

Bowman, J. P. (2000). Description of Cellulophaga algicola sp. nov., isolated from the surfaces of Antarctic algae, and reclassification of Cytophaga uliginosa (ZoBell and Upham 1944) Reichenbach 1989 as Cellulophaga uliginosa comb. nov. Int J Syst Evol Microbiol 50, 1861-1868.

Brettar, I., Christen, R. \& Höfle, M. G. (2004). Belliella baltica gen. nov., sp. nov., a novel marine bacterium of the CytophagaFlavobacterium-Bacteroides group isolated from surface water of the central Baltic Sea. Int J Syst Evol Microbiol 54, 65-70.

Cowan, S. T. \& Steel, K. J. (1965). Manual for the Identification of Medical Bacteria. London: Cambridge University Press.

Felsenstein, J. (1993). PHYLIP (Phylogeny inference package), version 3.5c. Distributed by the author. Department of Genome Sciences, University of Washington, Seattle, USA.

Glöckner, F. O., Fuch, B. M. \& Amann, R. (1999). Bacterioplankton composition of lakes and oceans: a first comparison based on fluorescence in situ hybridization. Appl Environ Microbiol 65, 3721-3726.

Holmes, B. R., Owen, R. J. \& McMeekin, T. A. (1984). Genus Flavobacterium Bergey, Harrison, Breed, Hammer and Huntoon 1923, 97 ${ }^{\mathrm{AL}}$. In Bergey's Manual of Systematic Bacteriology, vol. 1, pp. 353-361. Edited by N. R. Krieg \& J. G. Holt. Baltimore: Williams \& Wilkins.

Johnson, J. L. (1994). Similarity analysis of rRNAs. In Methods for General and Molecular Bacteriology, pp. 683-700. Edited by P. Gerhardt, R. G. E. Murray, W. A. Wood \& N. R. Krieg. Washington, DC: American Society for Microbiology.

Jukes, T. H. \& Cantor, C. R. (1969). Evolution of protein molecules. In Mammalian Protein Metabolism, pp. 21-132. Edited by H. N. Munro. New York: Academic Press. 
Kirchman, D. L. (2002). The ecology of Cytophaga-Flavobacteria in aquatic environments. FEMS Microbiol Ecol 39, 91-100.

McMahon, K. D., Dojka, M. A., Pace, N. R., Jenkins, D. \& Keasling, J. D. (2002). Polyphosphate kinase from activated sludge performing enhanced biological phosphorus removal. Appl Environ Microbiol 68, 4971-4978.

Murray, R. G. E., Doetsch, R. N. \& Robinow, C. F. (1994), Determinative and cytological light microscopy. In Methods for General and Molecular Bacteriology, pp. 21-41. Edited by P. Gerhardt, R. G. E. Murray, W. A. Wood \& N. R. Krieg. Washington, DC: American Society for Microbiology.

Nakagawa, Y., Sakane, T., Suzuki, M. \& Hatano, K. (2002). Phylogenetic structure of the genera Flexibacter, Flexithrix and Microscilla deduced from 16S rRNA sequence analysis. J Gen Appl Microbiol 48, 156-165.

Nakamura, L. K. (1987). Bacillus alginolyticus sp. nov. and Bacillus chondroitinus sp. nov., two alginate-degrading species. Int J Syst Bacteriol 37, 284-286.

Pandey, K. K., Mayilraj, S. \& Chakrabarti, T. (2002). Pseudomonas indica sp. nov., a novel butane-utilizing species. Int J Syst Evol Microbiol 52, 1559-1567.

Powers, E. M. (1995). Efficacy of the Ryu nonstaining $\mathrm{KOH}$ technique for rapidly determining Gram reaction of food-borne and waterborne bacteria and yeasts. Appl Environ Microbiol 61, 3756-3758.

Reasoner, D. J. \& Geldreich, E. E. (1985). A new medium for the enumeration and subculture of bacteria from potable water. Appl Environ Microbiol 49, 1-7.

Reichenbach, H. (1989). Genus I. Cytophaga Winogradsky 1929, $577^{\mathrm{AL}}$ emend. Reichenbach, H. In Bergey's Manual of Systematic Bacteriology, vol. 3, pp. 2015-2050. Edited by N. R. Krieg \& J. G. Holt. Baltimore: Williams \& Wilkins.
Saha, P. \& Chakrabarti, T. (2006). Emticicia oligotrophica gen. nov. sp. nov., a new member of the family 'Flexibacteraceae', phylum Bacteroidetes. Int J Syst Evol Microbiol 56, 991-995.

Saha, P., Krishnamurthi, S., Mayilraj, S., Prasad, G. S., Bora, T. C. \& Chakrabarti, T. (2005). Aquimonas voraii gen. nov., sp. nov., a novel gammaproteobacterium isolated from a warm spring of Assam, India. Int J Syst Evol Microbiol 55, 1491-1495.

Saitou, N. \& Nei, M. (1987). The neighbor-joining method: a new method for reconstructing phylogenetic trees. Mol Biol Evol 4, 406-425.

Simpson, J. M., Santo Domingo, J. W. \& Reasoner, D. J. (2004). Assessment of equine fecal contamination: the search for alternative bacterial source-tracking targets. FEMS Microbiol Ecol 47, 65-75.

Smibert, R. M. \& Krieg, N. R. (1994). Phenotypic characterization. In Methods for General and Molecular Bacteriology, pp. 607-654. Edited by P. Gerhardt, R. G. E. Murray, W. A. Wood \& N. R. Krieg. Washington, DC: American Society for Microbiology.

Stanley, T. W., Goodfellow, M. \& Alderson, G. (1989). Genus Streptomyces Waksman and Henrici 1943, 339 AL. In Bergey's Manual of Systematic Bacteriology, vol. 4, pp. 2452-2492. Edited by S. T. Williams. Baltimore: Williams \& Wilkins.

Thompson, J. D., Gibson, T. J., Plewniak, F., Jeanmougin, F. \& Higgins, D. G. (1997). The CLUSTAL_X windows interface: flexible strategies for multiple sequence alignment aided by quality analysis tool. Nucleic Acids Res 25, 4876-4882.

Van de Peer, Y. \& De Wachter, R. (1997). Construction of evolutionary distance trees with TREECON for Windows: accounting for variation in nucleotide substitution rate among sites. Comput Appl Biosci 13, 227-230.

Wang, Z.-W., Liu, Y.-H., Dai, X., Wang, B.-J., Jiang, C.-Y. \& Liu, S.-J. (2005). Flavobacterium saliperosum sp. nov., isolated from freshwater lake sediment. Int J Syst Evol Microbiol 56, 439-442.

Yoon, J.-H., Kang, S.-J. \& Oh, T.-K. (2005). Flavobacterium soli sp. nov., isolated from soil. Int J Syst Evol Microbiol 56, 997-1000. 